\title{
The Integration of Labour Standards Concerns into the Environmental and Social Policy of the International Finance Corporation
}

\author{
By Franz Christian Ebert*
}

\begin{abstract}
The present article examines how the International Finance Corporation (IFC), the World Bank Group's private sector finance institution, has integrated labour standards concerns into its environmental and social policy. Providing finance to companies in developing countries where available capital is often scarce, the IFC has significant economic leverage to influence the labour standards performance of private sector actors. Through its "Performance Standards", adopted in 2006, the IFC makes compliance with a broad set of labour standards a binding condition for access to its financial support. This also involves a procedural framework to bring client companies into compliance, including an external complaint mechanism under the World Bank's Compliance Advisory Ombudsman (CAO). However, a closer look reveals a number of shortcomings that may undermine the effectiveness of the Performance Standards in terms of fostering labour standards. These range from the Performance Standards' coherence with the ILO's Core Labour Standards to loopholes allowing companies to escape certain labour-related requirements by changing their business structure. Furthermore, the relevant procedures involve a high amount of discretion, which suggests that the ultimate outcomes will depend significantly on the goodwill of the body reviewing the complaint. Still, it appears that trade unions and NGOs have sometimes been able to use the Performance Standards to enforce labour standards vis-à-vis IFC client companies by triggering interventions by IFC staff and the CAO. Despite their limitations, it seems therefore that the IFC Performance Standards can at least occasionally serve as a tool for addressing labour standards problems in developing countries and should therefore be tested further.
\end{abstract}

* Research Fellow, Max Planck Institute for Comparative Public Law and International Law - ebert@mpil.de. This article draws in part on earlier work jointly published with Anne Posthuma. See notably Franz Christian Ebert / Anne Posthuma, Labour Standards and Development Finance Institutions: A Review of Current Policies and Activities, IILS Discussion Paper Series 204/2010, Geneva 2010. 


\section{Introduction}

Labour law, as a device for protecting workers, is facing difficulties. This is true not only in the developed world but also with regard to developing countries. In addition to often excluding certain workers from its scope, labour law is frequently subject to enforcement deficiencies, which are particularly rampant in the developing world. At the root of this in many cases are structural problems such as weak institutions, corruption, as well as "an extended culture of anomie". ${ }^{1}$ Because of such lapses in governance, the application of labour standards is in many developing countries in practice largely left to the discretion of private companies. This may also entail significant limitations to the enforcement of labour standards embodied in the International Labour Organization (ILO)'s conventions.

Stakeholders and academics have therefore raised the question of whether the enforcement of labour standards could be improved by harnessing the leverage of other international organizations. One of the actors in the spotlight of this debate has been the World Bank Group. ${ }^{2}$ While members of the World Bank Group have been criticized for the problematic impact of their policies on workers and have rejected the role of a labour standards enforcement agency ${ }^{3}$ they have gradually come to express their support for basic labour standards. ${ }^{4}$ Of most prominence has been the approach of the World Bank Group's private sector finance institution, the International Finance Corporation (IFC). Since 2006, the IFC requires client companies to observe a set of labour standards in order to be eligible for its financial services. ${ }^{5}$

As a provider of funds to the private sector in developing countries where available capital is scarce, the IFC has significant economic weight and therefore the possibility to exert influence on many local companies. In 2013, the IFC's new investment commitments amounted

1 See in this regard Tzehainesh Teklè, Labour Law and Worker Protection in the South: An Evolving Tension Between Models and Reality, in: Tzehainesh Teklè (ed.), Labour Law and Worker Protection in Developing Countries, Oxford / Geneva 2010, p. 35.

2 The term World Bank Group refers to a set of five institutions that are affiliated with but, legally speaking, separate from each other. The Group comprises the two institutions usually referred to as "World Bank", namely the International Bank for Reconstruction and Development and the International Development Association, as well as the International Finance Corporation, the Multilateral Investment Guarantee Agency, and the International Centre for Settlement of Investment Disputes. See further, Maurizio Ragazzi, World Bank Group, in: Rüdiger Wolfrum (ed.), Max Planck Encyclopedia of Public International Law, Oxford 2012, p. 909.

3 See on the former aspect M. Rodwan Abouharb / David Cingranelli, Human Rights and Structural Adjustment, Cambridge 2007, pp. 199-202. On the latter aspect see Adam McBeth, International Economic Actors and Human Rights, London / New York 2010, p. 179.

4 Peter Bakvis / Molly McCoy, Core labour standards and international organizations: What inroads has labour made?, Geneva 2008, pp. 5-7. On World Bank activities regarding labour standards see also Christine Kaufmann, Globalisation and Labour Rights. The Conflict between Core Labour Rights and International Economic Law, Oxford / Portland 2007, pp. 108-113.

5 For the most recent version see $I F C$, Performance Standards on Social \& Environmental Sustainability, Washington, 2012. 
to more than 18 billion US Dollars, covering 612 companies in 113 countries. ${ }^{6}$ A vigorous IFC policy regarding labour standards could hence help enforce labour standards in those countries. On the other hand, given the general policy thrust of the World Bank Group, known for its emphasis on deregulating labour law, suspicion may be in order as to whether the IFC's policies amount, in practice, to more than window-dressing aiming to appease its usual critics.

Against this backdrop, the present paper submits the IFC's environmental and social policy to an assessment as to its potential in furthering labour standards. It proceeds in four steps. Based on a brief overview of the evolution of the IFC's approach to labour standards (A.), the labour standards-related requirements of the IFC's environmental and social policy are examined. Attention will be drawn to some drawbacks of this policy that may undermine their practical effects and in part also prove the IFC's own statements about these standards wrong (B.). The paper then turns to how the IFC's environmental and social policy is actually implemented by reviewing the procedures and subsequently shedding light on first practical experiences (C.). The final section reflects on the potential of this policy as a tool for enforcing labour standards in developing countries.

\section{A. The evolution of the IFC's approach to labour standards}

The IFC's position regarding labour standards has been, just as that of other members of the World Bank Group, subject to considerable evolution. Initially, the World Bank refused unlike its sister organization the IMF - to fully endorse the ILO's concept of the Core Labour Standards due to its doubts as to whether trade unions rights had economically beneficial effects. ${ }^{7}$ In 2002, the Bank revised, however, its position in this regard and has ever since at least formally supported the ILO's concept of Core Labour Standards in its entirety. ${ }^{8}$ Similarly, the Bank has gradually accepted that the scope of its mandate does not preclude taking certain labour standards into account in the course of its operations. ${ }^{9}$

6 See IFC, The Power of Partnerships. Annual Report of 2013, Washington 2013, p. B. While IFC usually finances less than 25 percent of the project, its support is often crucial as this usually makes it easier for the company to obtain loans from other finance institutions. See in this regard Lowenfeld, International Economic Law ( $2^{\text {nd }}$ edition), Oxford 2008, p. 753.

7 Katherine A. Hagen, Policy Dialogue between the International Labour Organization and the International Financial Institutions: the Search for Convergence, Geneva 2003, pp. 19-20, 22-23.

8 See on this Bakvis / McCoy, note 4, p. 5. In its recent World Development Report on "Jobs", the World Bank defined "jobs" as income-generating activities that "do not violate fundamental principles and rights at work", as defined by the ILO's 1998 Declaration. See World Bank, World Development Report 2013. Jobs, Washington 2012, p. 66. On the general question of whether the World Bank is bound by certain international human rights obligations see Philipp Dann, The Law of Development Cooperation. A Comparative Analysis of the World Bank, the EU and Germany, Cambridge, 2013, pp. 267-272.

9 Francis Maupain, L'OIT à l'épreuve de la Mondialisation Financière. Peut-on regular sans contraindre?, Geneva 2012, p. 84-89. On the increasingly less restrictive interpretation of the World Bank's mandate see Mac Darrow, Between Light and Shadow: The World Bank, the International Monetary Fund and International Human Rights Law, Oxford et al. 2003, p. 152-154. 
In terms of integrating labour standards into operational policies, the IFC has taken a leading role within the World Bank Group. Already in 1998, the IFC adopted internal guidelines, prohibiting the financing of projects that involve forced labour as well as certain types of child labour. ${ }^{10}$ Following consultations with stakeholders, including the ILO, the IFC adopted a more comprehensive approach through its "Performance Standards on Environmental \& Social Sustainability" (hereinafter "Performance Standards"). ${ }^{11}$ The Performance Standards have been applied since May $2006^{12}$ and were revised after another public outreach exercise in $2011 .{ }^{13}$ In this regard, the IFC may have been influenced by certain national development finance institutions that had included labour standards requirements in their investment policies before or in parallel to the process undertaken by the IFC. ${ }^{14}$

The Performance Standards make compliance with a set of labour standards a condition for obtaining project finance from the IFC. As the Performance Standards become a binding part of the loan contracts it concludes with client companies, ${ }^{15}$ a breach of the Standards can lead to suspension of payment of the loan's tranches or to claims of reimbursement if the loan has already been disbursed. ${ }^{16}$ Apart from a chapter on labour standards, dealt with by the "Performance Standard 2", the Performance Standards contain a general part dealing with applicability and procedural issues as well as six other substantial parts. The latter address areas such as environmental issues, local communities, and indigenous peoples. ${ }^{17}$ Each Performance Standard is accompanied by a Guidance Note. While not being legally binding, the Guidance Notes provide orientation on how the IFC aims to construe and implement the Performance Standards. ${ }^{18}$ In terms of implementation, the approach used by the Performance Standards differs considerably from those of earlier IFC social and environmental policies

10 IFC, Policy Statement on Forced Labor and Harmful Child Labor, Washington 1998.

11 Emily Sims, The Promotion of Respect for Workers' Rights in the Banking Sector. Current Practice and Future Prospects, Paris 2008, p. 9. The IFC announced its intention to make any financial support subject to compliance with all four ILO Core Labour Standards already in 2003. See Bakvis / McCoy, note 4, p. 5.

12 See IFC, Policy on Social and Environmental Sustainability, Washington 2006; McBeth, note 3, p. 206 et seq.

13 See $I F C$, Performance Standards, note 5.

14 This includes, for example, the Danish Industrialisation Fund for Developing Countries (IFU). See Danish Industrialisation Fund for Developing Countries (IFU), Corporate Social Responsibility Policy, http://www.ifu.dk/dk/Material+Folder/Pdf/CSR-politik (last accessed on 17 April 2014).

15 McBeth, note 3, p. 211.

16 IFC, Policy on Social and Environmental Sustainability, Washington 2012, Para. 22.

17 The specific areas are "Resource Efficiency and Pollution Prevention, Community Health, Safety, and Security, Land Acquisition and Involuntary Resettlement, Biodiversity Conservation and Sustainable Management of Living Natural Resources, Indigenous Peoples, and Cultural Heritage". See $I F C$, Performance Standards, note 5, p. i.

18 IFC, International Finance Corporation's Guidance Notes: Performance Standards on Environmental and Social Sustainability, Washington 2012, p. ii.; McBeth, note 3, p. 214 on the 2006 version of the Guidance Notes. 
which mostly focused on one-time external impact assessments. ${ }^{19}$ Instead, the Performance Standards require companies to manage their "environmental and social performance" through their management systems and procedures throughout the entire business project. ${ }^{20}$ Apart from the said mandatory impact assessment, this also involves creating the necessary organizational capacity within the company and engagement with the stakeholders that are potentially affected by the project. $^{21}$

The Performance Standards have quickly become a reference point among other development finance institutions as well as among export guarantee agencies. ${ }^{22}$ One year after the adoption of the Performance Standards, the IFC's sister organization, the Multilateral Investment Guarantee Agency (MIGA), approved identical standards as conditions for its investment guarantees. ${ }^{23}$ Other institutions that have been influenced by the IFC Performance Standards include the European Bank for Reconstruction and Development (EBRD). EBRD has taken the Performance Standards expressly as a yardstick ${ }^{24}$ and the labour chapter of its Environmental and Social Policy adopted in 2008 is essentially a reproduction of the IFC Performance Standard 2, albeit with certain deviations. ${ }^{25}$ Furthermore, in the Environmental and Social Policies of the Netherlands Development Finance Company (FMO, after the Dutch denotation), the IFC Performance Standards serve as a minimum standard. This is to be observed by FMO's client companies where these are more far-reaching than relevant national standards. ${ }^{26}$ Finally, an important spill-over effect has taken place with regard to private sector banks through the so-called "Equator Principles". Adopted in 2003 by major banks operating in developing countries, these Principles set out the environmental and social standards and related risk management procedures that the "Equator Banks" commit to apply to their client companies. ${ }^{27}$ In 2006, these Principles were revised so as to incorporate the content of the IFC Performance Standards. ${ }^{28}$ Another revision took place in 2011 to align the Equator Prin-

19 Cf. Michael Warner, The new international benchmark standard for environmental and social performance of the private sector in developing countries: Will it raise or lower the bar?, London 2006, p. 2.

20 IFC, Performance Standard 1. Assessment and Management of Environmental and Social Risks and Impacts, Washington 2012, Para. 1.

21 IFC, Performance Standard 1, note 20, Paras. 17-19; 25-33.

22 See further Sims, note 11, p. 11.

23 MIGA, Performance Standards on Social \& Environmental Sustainability, Washington 2007.

24 A discussion paper drafted by EBRD staff recommended that EBRD's safeguard policy include all of the ILO's Core Labour Standards in order "[t]o match commitments by IFC and others". EBRD, Environmental Policy Discussion Paper, London 2007, p. 7, as cited in Bakvis / McCoy, note 4, p. 9.

25 Bakvis / McCoy, note 4, p. 9. This includes more demanding requirements regarding non-discrimination. See EBRD, Environmental and Social Policy, London 2008, p. 24.

26 FMO, Environmental and Social Policy, The Hague 2013, p. 2.

27 See further Andrew Hardenbrook, The Equator Principles. The Private Financial Sector's Attempt at Environmental Responsibility, Vanderbilt Journal of Transnational Law 40 (2006), p. 197 et seq.

28 Sims, note 11, p. 13 
ciples with the updated Performance Standards. ${ }^{29}$ Already in 2007, the Equator Principles were said to cover 80 percent of the financial activities of private banks in developing countries. $^{30}$

\section{B. Labour-related requirements in the IFC Performance Standards}

\section{Overview of substantive requirements}

The Performance Standards contain a variety of labour standards-related requirements, regarding both domestic labour law and general minimum standards. First and foremost, the Performance Standards require the client company to comply with the entire national labour law of the host state, which expressly includes international law incorporated into national law. ${ }^{31}$

Secondly, certain additional requirements regarding specific labour standards are defined. Notably, Performance Standard 2 contains requirements in the area of the ILO's Core Labour Standards, relating to the prohibition of forced labour and child labor, non-discrimination at the workplace, as well as freedom of association and collective bargaining. ${ }^{32}$ Furthermore, the client company must take certain measures in the field of occupational safety and health. ${ }^{33}$ The client company is required, in particular, to take measures with a view to minimizing the risk of accidents at the workplace, occupational diseases, and other hazards. This includes identifying causes of hazard, especially those endangering life, developing appropriate safety measures, relevant trainings, documenting accidents and diseases, as well as undertaking risk prevention measures. ${ }^{34}$

In terms of working and employment conditions, such as working time, leave, and wages, Performance Standard 2 does not set absolute minimum standards but draws on local stan-

29 See Equator Principles, Equator Principles, The Newly Revised IFC Performance Standards - Guidance on Implementation by EP Association Members From 1 January 2012, http://www.equator-pr inciples.com/index.php/all-ep-association-news/254-revised-ps (last accessed on 17 April 2014).

30 IFC, Banking on Sustainability. Financing Environmental and Social Opportunities in Emerging Markets, Washington 2007, p. 10.

31 IFC, Performance Standard 1, note 20, Para. 5.

32 IFC, Performance Standard 2. Labor and Working Conditions, Washington 2012, Paras. 13-17 und 21-22.

33 IFC, Performance Standard 2, note 32, Para. 23.

34 IFC, Performance Standard 2, note 32, Para. 23. The Guidance Note also addresses specific risks for female workers, such as sexual harassment in the workplace; see $I F C$, Guidance Note 2. Labor and Working Conditions, Washington 2012, Para. 76. In this regard, Performance Standard 2 and the respective Guidance Note refer to several World Bank documents, such as the World Bank Group Environmental, Health and Safety Guidelines and the Good Practice Note: Asbestos Occupational and Community Health Issues of the World bank Group. See IFC, Performance Standard 2, note 32, Para. 23 and $I F C$, Guidance Note 2, Paras. 77 and 79. Also, some ILO conventions are mentioned without going into the substance of their requirements; see $I F C$, Guidance Note 2, Para. 77. 
dards. ${ }^{35}$ Here, applicable collective agreements are given priority. Where these do not exist or do not regulate the question at stake, the client company is required to provide "reasonable working conditions and terms of employment". ${ }^{36}$ The meaning of this term is vague. ${ }^{37}$ According to the Guidance Note, the client company is expected to be in line with the usual conditions of the industry or the location. ${ }^{38}$

Certain standards must further be met with regard to retrenchments. ${ }^{39}$ This requires, first of all, an analysis of alternatives to the retrenchments. ${ }^{40}$ Where this is unsuccessful, a retrenchment plan must be put together, containing rules on the dismissal criteria, severance to be paid out, and alternative employment. ${ }^{41}$ As a transversal requirement, client companies are obliged to put in place a grievance mechanism at the company level, which should address workers concerns. ${ }^{42}$

The Performance Standards cover thus a wide area of issues relevant for the protection of workers. When looked at more in detail, the Performance Standards contain, however, a number of legal features that substantially reduce the protection offered by these Standards, which shall be set out below.

\section{The devil is in the details - a closer look at Performance Standard 2}

\section{Coherence with ILO “Core Labour Standards"?}

The provisions relating to the ILO's Core Labour Standards are a cornerstone of Performance Standard 2. The IFC does not fail to mention that Performance Standard 2 is "in part guided"

35 IFC, Performance Standard 2, note 32, Para. 10. This includes questions of overtime, breaks, and weekly rest periods as well as maternity leave and sick leave; IFC, Performance Standard 2, note 32, Para. 10, Footnote 5.

$36 I F C$, Performance Standard 2, note 32, Para. 10. This expressly includes migrant workers; see IFC, Performance Standard 2, note 32, Para. 11.

37 Performance Standard 2 provides only some indicia which these conditions are to be derived from, such as the average conditions in the sector or industry, the conditions stipulated in collective agreements of other companies in the same branch, arbitration awards, and the applicable domestic labour law. IFC, Performance Standard 2, note 32, Para. 10.

$38 I F C$, Guidance Note 2, note 34, Para. 25.

39 IFC, Performance Standard 2, note 32, Para. 18.

40 IFC, Performance Standard 2, note 32, Para. 18.

41 IFC, Performance Standard 2, note 32, Para. 18 as well as $I F C$, Guidance Note 2, Note 34, Para. 51. Also, the severance pay and outstanding wage payments must be provided within a reasonable timeframe. IFC, Performance Standard 2, note 32, Para. 19.

42 IFC, Performance Standard 2, note 32, Para. 20. 
by the ILO's Fundamental Conventions. ${ }^{43}$ Also, it proclaims that by "applying Performance Standard 2, the client will be able to operate its business in a manner consistent with the [ILO's Fundamental] Conventions". ${ }^{4}$

Indeed, Performance Standard 2 and the related Guidance Note refer to various ILO Conventions, Declarations, and Recommendations. ${ }^{45}$ In particular, the definition of the term "forced labour" draws heavily on the definition in the ILO's Forced Labour Convention, which is expressly referred to by the Performance Standard 2 Guidance Note. ${ }^{46}$ In other areas, coherence with the ILO's Conventions is, however, less far-reaching and does not amount to a full incorporation of the ILO Core Labour Standards into Performance Standard $2 .{ }^{47}$ As for child labour, for instance, the situation is somewhat ambivalent with regard to mandatory age limits. Though client companies are supposed to observe the respective age limits as provided for by ILO law, ${ }^{48}$ the related requirements are only included in the Performance Standard 2 Guidance Note. Meanwhile the text of Performance Standard 2 only obliges client companies to follow the relevant domestic law provisions on minimum age where they exist. ${ }^{49}$ Given the non-binding nature of the Guidance Note, it appears that client companies would not be re-

43 IFC, Performance Standard 2, note 32, Para. 2. The eight ILO Fundamental Conventions are Freedom of Association and Protection of the Right to Organise Convention, 1948 (No. 87); Right to Organise and Collective Bargaining Convention, 1949 (No. 98); Forced Labour Convention, 1930 (No. 29); Abolition of Forced Labour Convention, 1958 (No. 105); Minimum Age Convention, 1973 (No. 138); Worst Forms of Child Labour Convention, 1999 (No. 182); Equal Remuneration Convention, 1951 (No. 100); and Discrimination (Employment and Occupation) Convention, 1958 (No. 111). Other international instruments mentioned in this regard are Article 32(1) of the UN Convention on the Rights of the Child and UN Convention on the Protection of the Rights of all Migrant Workers and Members of their Families.

$44 I F C$, Guidance Note 2, note 34, Para. 2.

45 See also IFC, Guidance Note 2, note 34, Paras. 25, 28, 33, 34, 41.

$46 I F C$, Performance Standard 2, note 32, Para. 22 and IFC, Guidance Note 2, note 34, Para. 67. The definition used is , any work or service not voluntarily performed that is exacted from an individual under threat of force or penalty" (IFC, Performance Standard 2, note 32, Para. 22). Article 2 (1) of the ILO's Forced Labour Convention, 1930 (No. 29) states: "all work or service which is exacted from any person under the menace of any penalty and for which the said person has not offered himself voluntarily".

47 See with regard to the earlier version of Performance Standard 2 already Steven Herz / Kristen Genovese / Kirk Herbertson / Anne Perrault, The International Finance Corporation's Performance Standards and the Equator Principles: Respecting Human Rights and Remedying Violations?, A Submission to the U.N. Special Representative to the Secretary General on Human Rights and Transnational Corporations and other Business Enterprises, Washington 2008, p. 7.

48 The general age limit is 15 years. For developing countries, this limit can, under certain circumstances, be brought down to 14 years. Some types of light work can be carried out by children aged 13 or older. See Articles 2 and 7 of the ILO's Minimum Age Convention, 1973 (No. 138).

$49 I F C$, Performance Standard 2, note 32, Para. 21. Only for "hazardous work," a minimum age is foreseen. 
quired to respect the ILO standards on minimum age where this is not already mandated by domestic law. ${ }^{50}$

Similar lacks of coherence are apparent with regard to non-discrimination and trade union rights issues. While the client has to comply, in principle, with a number of requirements in this regard, these requirements are watered down for those countries that legally restrict those rights. For example, in countries where trade unions are prohibited, the client companies are only required not to hinder workers from establishing alternative mechanisms, such as workers' committees, and not to engage in anti-union discrimination and interference in union affairs. ${ }^{51}$ However, other requirements foreseen by the ILO's Fundamental Conventions, including in relation to collective bargaining, are not covered. ${ }^{52}$ Similarly, where national legislation foresees discrimination of workers, client companies are merely "encouraged" to carry out their activities in conformity "with the intent" of Performance Standard 2 but without infringing national law. ${ }^{53}$ For companies in those countries, compliance with the relevant ILO standards is thus again not a requirement. Admittedly, it is hard to see how the IFC could require its client companies to violate the national law of the host state. Also, it is debatable whether the alternative - not financing any project in such countries at all - would be desirable. This does, however, not alter the fact that the IFC's statement according to which compliance with Performance Standard 2 enables companies to be in line with the ILO's Core Labour Standards is, in light of the above, at best misleading.

\section{The scope of application - leaving companies a way out?}

The first question arising is which persons are actually covered by Performance Standard 2. The key criterion in this regard is the employment contract of the workers at stake. ${ }^{54}$ The main focus is on the workers directly employed by the client company. The substantive requirements of Performance Standard 2 apply to them in their entirety. ${ }^{55}$ The situation is, however, different for workers that only have indirect linkages with the client companies but that are still directly involved in carrying out the project at hand. In this regard, two types of workers can be distinguished.

50 See $I F C$, Guidance Note 2, note 34, Para. 61.

51 IFC, Performance Standard 2, note 32, Para. 13; IFC, Guidance Note 2, note 34, Paras. 37 and 39.

52 See on these obligations $I L O$, Freedom of Association. Digest of decisions and principles of the Freedom of Association Committee of the Governing Body of the ILO ( $5^{\text {th }}$ edition), Geneva 2006, Para. 925 et seq.

53 IFC, Performance Standard 2, note 32, Para. 16.

54 For the indicators to be taken into account for the determination of whether there is an employment relationship, Performance Standard 2 refers to ILO Recommendation No. 198 on the Employment Relationship, IFC, Guidance Note 2, note 34, Para. 5.

55 IFC, Performance Standard 2, note 32, Para. 5. 
The first category comprises workers that are employed by third party companies "to perform work related to core business processes of the project for a substantial duration". ${ }^{56}$ The term "core business" refers to any "production and/or service processes essential for a specific business activity without which the business activity could not continue". ${ }^{57}$ For these workers, the standard of protection is reduced in various ways. First, the requirements regarding retrenchment do not apply to third party companies. ${ }^{58}$ Second, regarding the other requirements, the client company does not need to ensure full compliance. Rather the client company only needs to "take commercially reasonable efforts to ascertain" that the third party company in question has a management system in place that enables it to carry out its activities in line with the relevant requirements of Performance Standard $2 .{ }^{59}$ The client company must also make "commercially reasonable efforts" to insert the relevant requirements into the contracts with the third party company. ${ }^{60}$ The main problem in this regard is the lack of determinacy of the terms used. For example, it may be difficult to determine in concrete cases whether the worker's contribution is so crucial for the business at hand that it can be considered a "core business" activity. ${ }^{61}$ Similarly, the term "commercially reasonable efforts" remains somewhat vague. The Guidance Note elucidates only that this term refers to measures that are not "uneconomical" from a business perspective and that this standard is lower than the "best effort" standard under which "excessively costly or burdensome" measures would also have to be considered. ${ }^{62}$

The protection offered by Performance Standard 2 is even further reduced in the case of workers that are employed by the client company's suppliers. Performance Standard 2 applies to any "primary supplier", which the Guidance Note defines as any supplier "providing goods, and materials essential for the core business processes of the project". ${ }^{63}$ The specific suppliers to be covered must be determined on a case-by-case basis considering the specific features of the supply chain. ${ }^{64}$ For the workers employed by suppliers, the client company's obligations are mainly limited to ensuring that no forced labour and harmful child labour are used. Where the assessment of the client company shows a "high risk" in this regard in the supply chain,

56 IFC, Performance Standard 2, note 32, Para. 4.

57 IFC, Performance Standard 2, note 32, Para. 4, Footnote 3.

58 IFC, Performance Standard 2, note 32, Para. 24.

59 IFC, Performance Standard 2, note 32, Para. 24. In some cases, this may include supporting the third party company's management system through the client company's system and shifting to another third party company where compliance flaws cannot be improved. See $I F C$, Guidance Note 2, note 34, Para. 85.

60 IFC, Performance Standard 2, note 32, Para. 25.

61 The Guidance Notes do not provide further guidance as to how this term should be construed, cf. IFC, Guidance Note 2, note 34, Para. 84.

62 IFC, Guidance Note 2, note 34, Para. 88.

63 IFC, Guidance Note 2, note 34, Para. 93. Covered may hence be certain suppliers with which the client company has only indirect business relations.

64 IFC, Guidance Note 2, note 34, Paras. 93-94. 
the client is required to monitor its primary suppliers and take, where necessary, measures to remedy the problem. ${ }^{65}$ Client companies are also required to take some action to protect health and safety standards vis-à-vis primary suppliers. However, this applies only if "a high risk of significant safety issues" is apparent in the supply chain; also, action is required only to ensure that "life-threatening situations" are avoided or remedied. ${ }^{66}$ Hence, a considerable possibility remains that parts of the supply chains of the IFC's client companies involve child and forced labour as well as other labour standards violations. ${ }^{67}$

Apart from a certain vagueness regarding the legal criteria involved, the main problem with these arrangements is that Performance Standard 2 does not provide any criteria for the outsourcing of work. Companies have hence full discretion in this regard and are, in principle, free to outsource activities even if this is not necessary or justified from a business perspective. Especially the delegation of activities to third party companies operating on the premises of the client company is a readily available device for companies aiming to circumvent the requirements of Performance Standard 2. ${ }^{68}$ The protection of workers provided by Performance Standard 2 depends thus to some extent on the benevolence of the client companies and can to a certain extent be reduced by them through the simple change of business structures.

3. Give with one hand and take with the other? The internal contradictions of IFC policies

While the Performance Standards have undoubtedly advanced the IFC's approach regarding the protection of labour standards, this effort has to some extent been thwarted by certain other policy instruments of the IFC. The most prominent example in this regard is the Doing Business Report, which is co-published annually by the IFC and the World Bank. Doing Business measures local business regulation on an annual basis for some 180 countries and ranks them according to their business friendliness. Eleven regulatory areas are covered, including establishing a company, obtaining finance, taxation issues and the enforcement of contracts. Doing Business has in no time become the most widely circulated World Bank publication and a reference point for policy-makers. ${ }^{69}$ This is particularly true for developing countries

$65 I F C$, Performance Standard 2, note 32, Para. 27.

$66 I F C$, Performance Standard 2, note 32, Para. 28. Where remedying the problems is not possible, the client company must remove on a mid-term perspective the primary supplier concerned from its supply chain. IFC, Performance Standard 2, note 32, Para. 29.

67 See for a similar observation regarding the earlier version of Performance Standard 2 already Halifax Initiative Coalition, One Step Forward, One Step Back. An Analysis of the International Finance Corporation's Sustainability Policy, Performance Standards and Disclosure Policy, Ottawa 2006, p. 11.

68 The Guidance Note only states that client companies should not engage in "disguised employment relationships" concealing its real nature or precluding the worker from the protection "they are due". See IFC, Guidance Note 2, note 34, Para. 8.

69 See Ralf Michaels, Comparative Law by Numbers? Legal Origins Thesis, Doing Business Reports, and the Silence of Traditional Comparative Law, The American Journal of Comparative Law 57 (2009), p. 772. 
for which comparable information is often difficult to obtain. ${ }^{70}$ For our purposes, the "Employing Workers" Index is of particular importance, which assesses the regulatory requirements imposed by the countries' labour laws on companies. ${ }^{71}$ Three areas are looked at in this regard, such as the hiring of workers, working and employment conditions (including minimum wage, working time, weekly rest periods, and leave) as well as the dismissal of workers.

By providing rankings of countries according to the flexibility of their (labour) legislation, Doing Business suggests that countries with high labour standards in the respective areas offer unfavourable business conditions to companies and labels these countries as problematic from an investor perspective. The thrust of Doing Business has thus, at least as far as labour law is concerned, been a deregulatory one. ${ }^{72}$ While not having any legal force, it exercises a significant amount of pressure on countries to lower standards in order to remain attractive for investors. Doing Business has also been used by both the World Bank and the IMF in its policy advice and as a condition for financial support to countries. ${ }^{73}$ It has therefore a considerable potential influence on domestic labour law, especially in countries that receive IMF and World Bank financial assistance. This is all the more problematic since the Employing Workers Index has been criticized by academics alleging methodological flaws, ${ }^{74}$ factual inaccuracies, ${ }^{75}$ and simplistic assumptions that are not backed up by the economic literature. ${ }^{76}$ Earlier versions of the Index also raised coherence issues, as the maximum score on certain points could only be obtained by disregarding the relevant ILO conventions on the matter. ${ }^{77}$

The Employing Workers Index of Doing Business raises significant coherence issues regarding the IFC's Performance Standard 2. As mentioned above, these standards crucially insist on compliance with domestic labour law and draw, in terms of working and employment conditions, on local standards. Through the Doing Business Report, IFC thus seems to envi-

70 Janine Berg / Sandrine Cazes, Policymaking Gone Awry: The Labor Market Regulations of the Doing Business Indicators, Comparative Labor Law and Policy Journal 29 (2008), p. 350.

71 See IFC / World Bank, Doing Business 2014, Washington 2013, p. 118.

72 Alvaro Santos, Labor Flexibility - Legal Reform and Economic Development, Virginia Journal of International Law 50 (2009), p. 63-64.

73 One example out of many is the case of Niger where recommendations of the Doing Business report provided the basis for the conditions regarding labour law reform. See Peter Bakvis, The World Bank's Doing Business Report: A Last Fling for the Washington Consensus?, Transfer (2009), p. 427.

74 See, e.g., Sangheon Lee / Deirdre McCann / Nina Torm, The World Bank's "Employing Workers" Index: Findings and Critiques - A Review of Recent Evidence, International Labour Review 147 (2008), p. 421-423; Santos, note 72, pp. 68-73.

75 Paul Benjamin / James Theron, Costing, Comparing, and Competing: The World Bank's Doing Business Survey and the Bench-Marking of Labour Regulation, in: Hugh Corder (ed.), Global Administrative Law: Development and Innovation, Claremont 2009, p. 227.

76 Berg/Cazes, note 70, p. 362.

77 See further Franz Christian Ebert, Kohärenz der Weltbank mit den arbeitsrechtlichen Mindeststandards der Internationalen Arbeitsorganisation?, in: Wolfgang Däubler / Reingard Zimmer (eds.), Arbeitsvölkerrecht, Baden-Baden 2013, pp. 81-82. 
sion lowering the same standards that it makes a condition for client companies elsewhere, thereby undermining its effects on the promotion of labour standards.

After increasing opposition to this Index by trade unions, the ILO, and the World Bank's Independent Evaluation Group, ${ }^{78}$ the World Bank instructed its staff in 2009 to stop using it in its advisory work and other activities. ${ }^{79}$ Also, the methodology of the Employing Workers Index was revised various times and, in 2011, the Index was relegated into an annex - with the ranking being removed ${ }^{80}$ The reports from 2012, 2013, and 2014 only included descriptive information as well as the raw country-level data related to the Index, mentioning that methodological revisions were underway. ${ }^{81}$ While the coherence problems in this regard have been alleviated to some extent, the current version of Doing Business continues to provide albeit unprocessed - comparative data on countries' labour laws. This, in combination with the Report's continued emphasis on the concern of "flexibility" of labour laws and avoiding "excessive rigidities", begs the question of whether the IFC is - through its Doing Business Report - not biting the hand that feeds its Performance Standards. ${ }^{82}$

\section{Implementing the labour standards requirements of the Performance Standards}

\section{The procedural framework - labour standards protection at IFC's discretion?}

1. The due diligence procedure

The procedure for the implementation of the Performance Standards is laid down in the IFC's "Policy on Environmental and Social Sustainability" (hereinafter: "Policy") and draws heavily on the concepts of risk analysis and management used by private sector finance institutions. The main objective behind this procedure is to identify the social and environmental risks arising from the projects at an early stage and to develop strategies to avoid or at least mitigate them. The IFC works with companies to remedy problems over time rather than just excluding these companies from IFC finance. ${ }^{83}$ For this purpose, the IFC carries out an impact assessment on the basis of the requirements of the Performance Standards within the framework of its general due diligence. ${ }^{84}$ For direct investments, this due diligence exercise may involve a

78 Independent Evaluation Group, Doing Business: An Independent Evaluation. Taking the Measure of the World Bank- IFC Doing Business Indicators, Washington 2008, p. 6.

79 World Bank, Guidance Note for World Bank Group Staff on the Use of the Doing Business Employing Workers Indicator for Policy Advice, Washington 2009, pp. 1-2. See also Bakvis, note 73, p. 431.

80 IFC/World Bank, Doing Business 2011, Washington 2010, p. 94.

81 IFC/World Bank, Doing Business 2012, Washington 2011, p. 23; IFC/World Bank, Doing Business 2013, Washington 2012, p. 16.

82 See IFC/World Bank, Doing Business 2014, Washington 2013, p. 118.

83 IFC, Policy on Environmental and Social Sustainability, Washington 2012, Para. 45.

84 IFC, Policy, note 83, Para. 21. 
review of relevant documents, site visits and interviews, among others. ${ }^{85}$ A key source in this regard is the client company's own impact assessment, which the client company is obliged to carry out under Performance Standard $1 .{ }^{86}$

Where the results lead to the conclusion that the risks arising from the project cannot be managed, IFC staff is required to reject financing the project. ${ }^{87}$ Other projects are put into different groups according to the risks and potential impacts involved, which entail different implications in terms of risk monitoring and management. ${ }^{88}$ If significant risks are identified, the client company is required to address them by means of an action plan. ${ }^{89}$ These action plans are incorporated into the loan contract, including the specific objectives and indicators,${ }^{90}$ and non-compliance may entail contractual consequences. The Policy also foresees regular monitoring of the clients' performance, including in the form of "annual monitoring reports" that the client company is required to submit to the IFC. ${ }^{91}$

While this Policy establishes a comprehensive framework for addressing problems relating to labour standards, it also provides IFC staff with significant discretion as to how to carry out the due diligence and how to deal with possible compliance issues. Among others, staff has considerable leeway in terms of how and with which devices they conduct the due diligence exercise. ${ }^{92}$ Also, the Policy leaves it open under which timeframe compliance problems must be addressed and how severe these have to be in order to bring about contractual sanctions. ${ }^{93}$ Despite its technical appearance, the implementation procedure involves thus an important political component. As a consequence, the implementation of the Performance Standards depends to a palpable extent on the goodwill of the relevant IFC staff members.

Furthermore, the important role that the Performance Standards assign the client company in the due diligence exercise has repeatedly been criticized. The IFC's strong reliance on the assessment by the company itself or by a consultant hired by the company puts the independence of the due diligence exercise at risk. ${ }^{94}$ The reason for this is that client companies may have an interest to minimize the problems identified in order to reduce the costs related to the

85 IFC, Policy, note 83, Para. 28. Specific rules (involving a somewhat reduced standard) exist for investments the IFC makes through financiary intermediaries and for the IFC's advisory activities. See $I F C$, Policy, note 83, Paras. 32-37 and 38-39.

86 IFC, Performance Standard 1, note 20, Para. 7.

87 IFC, Policy, note 83, Para. 22.

88 IFC, Policy, note 83, Para. 40.

89 IFC, Performance Standard 1, note 20, Para. 16.

90 IFC, Policy, note 83, Para. 24.

91 IFC, Policy, note 83, Para. 45.

92 The elements mentioned in the Policy, such as document review, site visits, etc., have only indicative quality. Cf. IFC, Policy, note 83, Para. 28.

93 The Policy merely provides that „,[p]ersistent delays in meeting these requirements can lead to loss of financial support from IFC". See IFC, Policy, note 83, Para. 22.

94 See e.g. ITUC, Labour Standards in World Bank Group Lending. Lessons Learned and Next Steps, 2011 , p. 13. 
Performance Standards. ${ }^{95}$ According to some, Performance Standard 2 is therefore likely to be effective mainly in cases where trade unions are in place that can independently monitor the compliance with these standards ${ }^{96}$ which is by far not the case in all countries where the IFC operates. It has therefore been proposed to flank the companies' impact assessments systematically with assessments by independent experts in order to ensure an objective evaluation of the risks involved in the relevant projects. ${ }^{97}$

\section{The complaint procedures}

In addition to the procedure described above, interested parties have the possibility to raise grievances relating to the non-observance of the Performance Standards by an IFC client company. This can mainly be done in two ways. First, interested parties can turn to the IFC's Environmental and Social Development Department to have the matter reviewed by IFC staff. ${ }^{98}$ Trade unions have made use of this option in a number of cases. ${ }^{99}$

Second, a formal grievance mechanism before the so-called "Compliance Advisory Ombudsman" (CAO) has been put in place. Reporting directly to the World Bank Group's president, the CAO is an organ of the World Bank Group but is independent of the operational business of the IFC. ${ }^{100}$ The CAO's responsibilities are three-fold. It involves resolving complaints by interested parties (ombudsman function), investigating potential infringements of the IFC's - as well as the MIGA's - environmental and social policies (compliance function), and providing advice to both institutions (advisory function). ${ }^{101}$

The procedural framework for the CAO complaint mechanism is set out in the CAO's Operational Guidelines. ${ }^{102}$ Complaints can be filed with the $\mathrm{CAO}$ by anyone and can concern

95 McBeth, note 3, p. 215.

96 See Bakvis / McCoy, note 4, p. 7; Özge Berber Agtas, Promoting core labour standards through the Performance Standards of the IFC: The case of Turkey, Global Union Research Network Discussion Paper No.8, Geneva 2009, p. 43.

97 McBeth, note 3, p. 215. See for a similar point, Reingard Zimmer, Soziale Mindeststandards und ihre Durchsetzungsmechanismen, Baden-Baden 2008, p. 205 et seq.

98 A trade union guide on the IFC Performance Standards also points at the possibility to raise labour standards problems with "labour friendly" World Bank Executive Directors, see ITUC, A Brief Guide to Using the IFC Performance Standards, Washington 2009, p. 1.

99 See ITUC, 2009, note 98, p. 2 et seq.

100 Benjamin Saper, The International Financial Corporation's Compliance Advisor/Ombudsman (CAO): An Examination of Accountability and Effectiveness from a Global Administrative Law Perspective, International Law and Politics 44 (2012), p. 1295.

101 See CAO, Operational Guidelines, Washington 2007, p. 7.

102 For a concise overview, see Daniel D. Bradlow, Private Complainants and International Organizations: A Comparative Study of the Independent Inspection Mechanisms in International Financial Institutions, Georgetown Journal of International Law 36 (2005), pp. 432-437. 
any aspect of the planning and implementation of projects with the IFC and the MIGA, ${ }^{103}$ even beyond the Performance Standards. ${ }^{104}$ The only requirement is that they concern the project's social or environmental effects and allege that the complainant's interests are affected. ${ }^{105}$ The CAO looks at admissible complaints first under its Ombudsman function, which may involve file analysis, hearings, interviews, as well as site visits. ${ }^{106}$ Based on this, the CAO takes action to facilitate an amicable settlement of the matter between the parties. ${ }^{107}$ This may include commitments by the client company to address certain project effects that are disadvantageous for the complainant, where appropriate involving the IFC and the MIGA. ${ }^{108}$

If no settlement is reached, the CAO's compliance function is automatically activated. ${ }^{109}$ Where a preliminary assessment of the case leads to the identification of potential breaches of the Performance Standards that justify further investigation, an audit of the company will be carried out. ${ }^{110}$ In this regard, the political dimension of the procedure becomes particularly palpable. The CAO has significant discretion regarding the question of how to conduct such an investigation, which may, for example, involve the use of external experts. ${ }^{11}$ More importantly, the question as to whether an investigation should be initiated at all is largely left to the discretion of the CAO. ${ }^{112}$ The criteria used in the Operational Guidelines to determine when the CAO should prepare an audit are rather broad, involving the need for "substantial concerns" regarding social and environmental matters ${ }^{113}$ and the general criterion of assessing "whether an audit is the appropriate response". ${ }^{114}$ This provides the CAO ample possibilities to refrain from entering into cases that are of political sensitivity, showing a clear focus on flexibility as the procedural rationale. ${ }^{115} \mathrm{Also}$, the fact that the $\mathrm{CAO}$ is required

$103 C A O$, Operational Guidelines, note 101, pp. 11-12. The future or probably participation of IFC or MIGA is sufficient in this regard, ibid, p. 15.

104 See also Saper, note 100, p. 1298.

105 See $C A O$, Operational Guidelines, note 101, p. 15. By contrast, bad faith and trivial complaints as well as complaints that aim to obtain a competitive advantage are not admissible.

106 See CAO, Operational Guidelines, note 101, p. 16. See also Björn Arp, El Banco Mundial entre el apoyo a grandes inversiones y la protección de los derechos humanos. Estudios sobre el "Ombudsman" y Asesor en Materia de Observancia de la Corporación Financiera Internacional, Revista Instituto Interamericano de Derechos Humanos 55 (2012), pp. 141-142.

$107 C A O$, Operational Guidelines, note 101, p. 16 . On the admissibility requirements see $C A O$, Operational Guidelines, note 101, p. 15.

108 See $C A O$, Operational Guidelines, note 101, p. 17.

109 See $C A O$, Operational Guidelines, note 101, p. 18. The compliance procedure can also be triggered by the IFC's senior management or by the CAO itself; see ibid, p. 22.

110 CAO, Operational Guidelines, note 101, pp. 18, 22.

111 CAO, Operational Guidelines, note 101, p. 24.

112 Cf. Saper, note 100, p. 1303.

113 CAO, Operational Guidelines, note 101, p. 22.

114 CAO, Operational Guidelines, note 101, p. 23.

115 See also Bradlow, note 102, pp. 459-460. 
to consult with the IFC and/or the MIGA on the whether or not to prepare an audit ${ }^{116}$ makes it seem possible that in some cases political influence could be used to put pressure on the CAO for that purpose.

Where the CAO does decide to examine the case, its investigation culminates in a report ("audit"), determining whether the requirements of the relevant policies had been respected. ${ }^{117}$ In the event of a breach, the CAO is supposed to monitor the case until it is satisfied that the measures taken will remedy the breach. ${ }^{118}$ Here, too, a considerable political element is apparent. In particular, the CAO's findings do not have any legal effect on the IFC or the MIGA even though they may put political pressure on them to remedy possible violations. ${ }^{119}$ Also, while the relevant reports of the CAO are in principle public, the President of the World Bank Group may prohibit publication of the compliance reports. ${ }^{120}$ In light of this, it appears crucial for assessing the effectiveness of the Performance Standards to look at how these provisions have been applied in practice, which is what the next section will turn to.

\section{Furthering labour standards in spite of itself? A glance at the practical effects}

Despite their limitations in terms of substance and procedure, it appears that the Performance Standards have in a number of cases been successfully used to enforce labour standards. While information on the effects of the IFC's due diligence procedure is hard to obtain, the complaints filed with the IFC and the CAO, respectively, allow for a more thorough assessment.

Action by IFC staff, who have so far dealt with the bulk of the relevant cases direct$1 y,{ }^{121}$ seems in certain cases to have contributed to addressing labour standards issues under the Performance Standards. A trade union report from 2009 lists 17 cases regarding labour standards that had been raised with the IFC. ${ }^{122}$ According to the report, in five cases the client companies concerned remedied the breaches alleged, which the unions have attributed to the interventions of IFC staff. ${ }^{123}$ An illustrative example is the case of the Brazilian flight company GOL Airlines, which had received a loan by the IFC. Here, a number of allegations had been raised involving anti-trade union activities carried out by the company. Further to trade unions raising the issue, IFC staff engaged in discussions with the company, which, in the view of union officials, made the company correct its action in this regard. ${ }^{124}$ Another case concerned

$116 C A O$, Operational Guidelines, note 101, p. 23.

117 CAO, Operational Guidelines, note 101, p. 18, 26.

118 See $C A O$, Operational Guidelines, note 101, p. 26.

119 See $C A O$, Operational Guidelines, note 101, p. 26.

120 See $C A O$, Operational Guidelines, note 101, p. 25.

121 See ITUC, 2009, note 98, p. 1.

122 See ITUC, 2009 , note 98, p. 7 et seq. In other cases, the project was withdrawn or additional monitoring of labour standards took place. In one case, IFC rejected the complaint filed by trade unions arguing that a compliance issue regarding the Performance Standards was not apparent; see ibid.

123 See ITUC, 2009, note 98, p. 7 et seq.

124 See Bakvis / McCoy, note 4, p. 6. 
a construction company operating in Uganda, which had concluded a collective agreement with a local trade union but had then refused to apply the agreement to its workers. Again, trade unions raised the case with the IFC, which in turn appears to have persuaded the company to properly apply the agreement. ${ }^{125}$ This may to some extent have been facilitated by certain internal action the IFC has taken to render its staff more sensitive to labour concerns as well as to social and environmental concerns more broadly. The IFC has, for example, recruited specialized staff for the implementation of the Performance Standards, including several experts on labour issues. ${ }^{126}$ In addition, the IFC has imparted face-to-face and online training to a number of staff members ${ }^{127}$ and established a specific Labour Advisory Group to provide advice on IFC activities. ${ }^{128}$

In addition, the CAO's activities have in some cases had a role in terms of resolving labour standards concerns. As of April 2014, about a dozen cases involving labour standards issues had been raised with the CAO, two of which on the initiative of the CAO Vice President. ${ }^{129}$ The cases concerned trade union rights as well as other issues, such as occupational safety, health and wages. In some cases, the CAO's mediation efforts proved to be successful. One example in this regard is the case of the Turkish automobile supplier Standard Profil of 2008, which involved matters relating to workers' freedom of association as well as other labour standards. ${ }^{130}$ In this case, the CAO carried out a rather comprehensive assessment at the ombudsman stage, which also involved a visit of the company site. ${ }^{131}$ Based on this assessment, the CAO recommended a number of measures that were accepted by the parties. ${ }^{132}$ This involved several training activities with a view to building capacity and increasing awareness regarding labour standards issues among the company's managers and employees. Other

125 See Fiona Murie, BWI Strategies to Promote Decent Work Through Procurement: The Example of the Bujagali Dam Project in Uganda, GURN Discussion Paper; No. 9, Geneva 2009, p. 15-16.

$126 I F C$, IFC's Policy and Performance Standards on Social and Environmental Sustainability and Policy on Disclosure of Information: Report on the First Three Years of Application, Washington 2009, p. 12.

127 In 2009, this had amounted to 1600 face-to-face trainings of IFC and World Bank staff while 192 staff members completed an online course on those issues. IFC, Three Years, note 126, p. 5.

$128 I F C$, Three Years, note 126, p. 12. Such training has mostly been carried out by independent consultants rather than, for example, by the staff of the ILO. Lee Swepston, International Finance Institutions and Labour Standards, http://qr.jur.lu.se/Quickplace/jamr09/Main.nsf/0/5A75D53899D 4CB27C1257BCF003355CE/\$file/LS\%20StudyFinal\%20draft\%2026\%20Jan2012.pdf (last accessed on 17 April 2014), p. 13.

129 See the CAO's database on cases filed at http://www.cao-ombudsman.org/cases/ (last accessed on 17 April 2014).

130 See in this regard also Björn Arp, La Integración de los Derechos Humanos en la Labor del Banco Mundial, Revista Española de Derecho Internacional 64 (2012), pp. 37-38.

131 See further $C A O$, Turkey / Standard Profil-01/Duzce. Stakeholder Assessment, Regarding Labor Rights Concerns at Standard Profil, Turkey - 2 February 2009, p. 4.

132 CAO, Turkey / Standard Profil-01/Duzce. Ombudsman Conclusion Report - Standard Profil, Turkey, June 2012, p. 2. 
agreed measures included an independent assessment of the labour standards of the company. ${ }^{133}$

By contrast, other cases have produced fewer results in terms of resolving labour standards issues and highlight the political nature of the complaint procedures. This was notably true for a complaint submitted in 2008 to the IFC regarding the Colombian flight company Avianca, involving issues regarding workers' freedom of association and collective bargaining rights. Whilst IFC staff conducted two labour-related audits on Avianca, these were perceived as ineffective and results were allegedly in part not shared with the complainants. ${ }^{134}$ In light of these results, the trade unions subsequently took the case to the CAO for mediation. However, after the company had rejected to engage in any mediation exercise on the matter, the CAO initiated a compliance procedure in June 2012. ${ }^{135}$ Yet, despite the rather straightforward case, it took the CAO nine months to put the terms of reference for the audit together and the investigation was still pending as of April 2014. ${ }^{136}$ In light of the antecedents, it does not seem far-fetched that political concerns may have affected the handling of the case. The political dimension of the procedure is also exemplified by a complaint of 2001 regarding an oil company operating in the Niger Delta, alleging labour standards violations by the client's contractors, among others. ${ }^{137}$ Here, the $\mathrm{CAO}$ conducted mediation activities and proposed various recommendations to the parties, which did however not address the labour standards issues raised. ${ }^{138}$ When the complainants rejected the recommendations made, the CAO closed the case without the case being transferred to the compliance stage, which left the relevant labour standards issues untreated. ${ }^{139}$

Finally, it appears that the effectiveness of the CAO procedure and the Performance Standards more generally is reduced by the fact that many of those affected lack knowledge about the procedure as well as the involvement of the IFC in the relevant project, which prevents them from filing complaints. ${ }^{140}$ In spite of the above, the Performance Standards have still contributed to making a number of the IFC's client companies change their behaviour even

133 See in this regard Berber Agtas, note 96, pp. 38-89.

134 See ITUC, Labour Standards in World Bank Group Lending. Lessons Learned and Next Steps, Washington 2011, p. 23.

135 See $C A O$, Case Summary. Colombia / Avianca-01/Colombia, http://www.cao-ombudsman.org/ca ses/case_detail.aspx?id=182 (last accessed on 17 April 2014).

136 See $C A O$, Colombia / Avianca-01/Colombia. Terms of reference for audit of IFC, Case of Complaint from Global Unions on behalf of unions representing employees of Avianca, 16 April 2013.

137 See CAO, Case Summary. Nigeria / Niger Delta Contractor Revolving Credit Facility-01/Niger Delta. http://www.cao-ombudsman.org/cases/case_detail.aspx?id=106 (last accessed on 17 April 2014).

138 See $C A O$, Nigeria / Niger Delta Contractor Revolving Credit Facility-01/Niger Delta, Assessment Report, August 2001, p. 5.

139 See CAO, Case Summary. Nigeria / Niger Delta Contractor Revolving Credit Facility-01/Niger Delta. http://www.cao-ombudsman.org/cases/case_detail.aspx?id=106 (last accessed on 17 April 2014).

140 Saper, note 100, p. 1318. 
if the outcomes vary from case to case. This is also recognized by trade union organizations that are in general rather critical of the World Bank Group. ${ }^{141}$

\section{Conclusion}

The present article has examined how the IFC has integrated labour standards into its Environmental and Social Policy. It has shown that the IFC has - compared to other International Financial Institutions - taken a progressive stance in this regard. This has been done by adopting specific labour-related Performance Standards as a condition for its financial support, which have become a reference point for development finance institutions as well as for private banks operating in developing countries.

While the Performance Standards address a number of labour standards, they show several substantial limitations at second glance. In particular, the Performance Standards do not live up to the IFC's statement that complying with them enables client companies to avoid violations of the ILO's Core Labour Standards. Indeed, the Performance Standards deviate from the latter in various respects. Also, the Performance Standards leave companies various possibilities to circumvent the relevant requirements by modifying their business structures, notably by outsourcing work to contractors or outside suppliers. In addition, the Performance Standards have, to some extent, been undermined by other IFC policy devices, such as the Employing Workers Index of the Doing Business Report.

As to the implementation of the Performance Standards, the procedures put in place provide an elaborate framework for addressing labour standards both before and after the IFC decides on financing a given business project, including through external review by the CAO. These procedures accord, however, a significant amount of leeway to both the IFC and the $\mathrm{CAO}$, in terms of whether and how the review of the issues at hand is carried out. This suggests that the ultimate outcomes will depend significantly on the goodwill of the reviewing body. This applies also to the $\mathrm{CAO}$, which is somewhat - but certainly not completely - independent from the IFC's institutional and political context. Other limitations include the strong reliance by the IFC on the client company's self-assessments during the due diligence procedure. Since client companies have an economic interest not to reveal compliance problems in order to avoid costly remedial measures, this runs the risk of undermining the impact of this procedure.

Despite these substantive and procedural limitations, it has turned out that the Performance Standards did contribute, in a number of cases, to improving the application of labour standards in practice. Trade unions seem to have been able to use the Performance Standards as a device to remedy labour standards problems in some of the IFC's client companies by raising these issues directly with IFC staff, which seems to have shaped up its expertise on labour standards in recent years. Furthermore, there is evidence that some labour standards problems have been remedied through the CAO complaint mechanism. There are also, however, cases

141 See e.g. ITUC, 2011, note 134, p. 14. 
where the IFC and the CAO appear to have used their discretion to either close the case without the labour standards problem being resolved or to protract the issues at hand.

Overall, the above findings suggest that the IFC Performance Standards amount, in spite of their various shortcomings, to more than mere window-dressing. Indeed, it appears that they can, at least occasionally, serve as a tool to enforce labour standards vis-à-vis the IFC's client companies in contexts where other remedies are often sparse. As to whether the Performance Standards could be a real stepping stone for the enforcement of labour standards is too premature to determine. The fact that only about one fifth of the IFC's client companies seem to think that the Performance Standards might have a negative effect on their interest to collaborate with the IFC ${ }^{142}$ may be read as a positive sign but could also serve as an indication that the practical effects of these Standards are limited. Also, the IFC Performance Standards only cover a fairly limited percentage of the workforce in developing countries, mainly in the formal sector, so that extensive transformative effects should not be expected. The future effects of the Performance Standards will also depend on how the IFC's investment strategy evolves and whether it will retain its focus on directly financing business projects rather than on investment through financial intermediaries where its leverage on companies is considerably smaller. Furthermore, it remains to be seen whether the IFC will remedy the substantial and procedural shortcomings outlined above and, most notably, whether it will devote the necessary political energy to the implementation of these Standards even where the latter may go against powerful economic or political interests. For the time being, worker rights organisations should be encouraged to continue to put the sincerity of the IFC's commitments to the test.

142 According to a survey carried out by the IFC among its client companies, 60 percent of the companies interviewed considered that business expenses under the IFC Performance Standards exceeded the average costs in the relevant sector. Notwithstanding, only 21 percent of them stated that their inclination to work with the IFC might be reduced due to the Performance Standards; see $I F C$, Three Years, note 126, p. 22. 